\title{
"Beneficial OWNers" Policy: Comparison of Its EFFicaCy in The West With Prospects for CURbing CORRUPTION IN CHINA
}

\author{
Daniel Zigo $^{1}$, Filip Vincent ${ }^{2}$
}

\begin{abstract}
Registers that collect data on beneficial owners, individuals who, either directly or indirectly, has the power to control companies or enjoy the benefits of ownership, are being implemented in many countries as part of the AML measures. Governments here want to know benefits from a company, to prevent money laundering or financing of terrorists. However, what is not common is the use of such a register to fight corruption. Slovakia has created a special model of the beneficial ownership registry, aimed at financial relations of the state with the private sector, so the information on who benefits from state funds is publicly available. In this context, we were interested in China and the regulation beneficial owners in this country, because, similar to Slovakia, the phenomenon of corruption is here a widespread problem, especially in the field of public procurement. Moreover, an anticorruption campaign, aimed to clean the relations between the public and private sector, is still ongoing in China. The focus of this article is, therefore, a broad question about institutionalizing control of corruption: Could registration of beneficial owners be legally and technically transferred to the People's Republic of China to help institutionalize the country's anti-corruption campaign?
\end{abstract}

\section{Keywords}

Public Procurement, Beneficial Owners, Registry, Anti-corruption

\section{Introduction}

One of the major societal problems in many countries around the world is corruption. There are many definitions of corruption in legal or sociological science, but in general, it is a phenomenon where a person deviates from the formal duties of a public role for private

\footnotetext{
${ }^{1}$ Comenius University in Bratislava, Šafárikovo námestie 6, 81000 Bratislava, Slovakia. E-mail: daniel.zigo@flaw.uniba.sk.

${ }^{2}$ Comenius University in Bratislava, Šafárikovo námestie 6, 81000 Bratislava, Slovakia.

E-mail: filip.vincent@flaw.uniba.sk.
} 
(personal, family, or group-oriented) interests, for financial or other gain or behaviour that violates rules to increase private influence (Nye, 2017, p. 418). A common characteristic is the abuse of power for personal gain. Public officials need certain powers to be able to fulfil the public interest, but these bring opportunities for their abuse, including corruption (Mihalik et al., 2019, p. 119). However, corruption as such can take many different forms, with bribes being just one of them, and may include criminal activities, activities that are borderline or cases of behaviour that is not illegal but at least inappropriate (Neshkova and Rosenbaum, 2015, p. 100). Similarly, various entities, whether governmental or the private sector, may be involved in corruption. Despite the relatively difficult quantification of the volume of corruption in the state, due to the fact that it is a highly latent activity, public opinion perceives its existence in society, which is being confirmed by various surveys conducted by international or non-profit organizations. Public opinion and fears of losing legitimacy in the eyes of citizens are just some of the reasons why countries are trying to curb corruption. Economic aspects are also very important, according to various estimates, corruption costs countries globally trillions of dollars per year. What is happening, for example, by reducing the volume of taxes collected, damaging the performance of the economy and competition, the ability of businesses, or discouraging foreign investments (Graycar, 2020, p. 1).

The area of public procurement is particularly vulnerable to corruption. The public and private sectors are in an economic interaction with each other, and the state spends a significant part of the state budget through public procurement. There are, therefore, many opportunities for corrupt behaviour, and the spread of corruption in the process of public procurement is supported by many objective and subjective factors. One of them is the fact that the efficiency and effectiveness of spending funds are generally lower in the public sphere than in the private sector (Mandl et al., 2008, p. 28). From a subjective point of view, a person distributing public funds may want to use such power for personal gain, especially if there is a lack of transparency in the given process. The public and the media are sensitive to corruption cases and scandals, but to be able to react, they must have access to information. Therefore, there is pressure for greater transparency of the state, especially in spending public funds. As countries begin to reform their legal system to increase transparency, such reforms have a significant impact on corruption and its perpetrators, they create barriers that require more sophisticated methods from the perpetrators of economic crimes to overcome (Blazo and Kovacikova, 2019, p. 226).

One of the more sophisticated methods by which companies avoid transparency is to use offshore entities, i.e. foreign companies based in jurisdictions ${ }^{3}$ where corporate law is highly flexible. These offshore entities allow anonymity of the corporate structure, low or no tax burden for entrepreneurs, and reduced requirements for company accounting. The banking system in the given jurisdictions is also adapted to these conditions and is characterized by undemanding conditions for bank account opening and emphasizes the

\footnotetext{
${ }^{3}$ In this sense, the term jurisdiction is generally used to refer to any territory that has its own legal system, regardless of whether it is an independent or sovereign state; where appropriate, part of a federal (e.g. Delaware) or Confederate state, an associated or overseas territory (e.g. the British Virgin Islands) or a national zone under which a special legal regime applies (e.g. Hong Kong).
} 
confidentiality of information about clients. The mentioned basic attributes: anonymity, tax minimization, easy access to funds, asset management, and their security, are the main advantages for which entrepreneurs decide to use foreign jurisdiction to establish a company (Henry, 2012, p. 10). Offshore shell company can serve legal and legitimate purposes, e.g. as a holding company, but it can be used also for illegal activities, with perpetrators abusing its "corporate veil" (Findley, 2012, p. 7). Advanced efforts to hide the ownership structure of companies also place higher demands on the government counter-measures. Regulations on beneficial owners are part of such measures and these are fundamentally connected with the topics of corruption, offshore companies, and transparency.

This paper aims to bring the Slovak beneficial ownership regulation closer to the readers' attention. Our interest in this regulation is based on a fact that it was designed to fight corruption. This measure is interesting in relation to China, which in the previous decade embarked on the path of fighting corruption. Although it may not seem obvious, Slovakia and China have more in common than just the fight against corruption. From a historical, social and legal point of view, these two countries had similar development during the past 50 years. Until 1989, Slovakia was a socialist country (and similar to China), its legal system was based on the Soviet model. After the reform and opening-up in China from 1978 and the fall of socialism in Slovakia in 1989, the two countries have developed differently, but both faced similar social issues. Corruption was (and still is) one of the many problems that the states of Eastern Europe had to face after the fall of socialism. Of course, this issue is not linked exclusively to the socialist state establishment, but the transition from a centrally controlled economy, where the state owns most means of production and enterprises, brought many opportunities for the possibility of illegal activities (Ledeneva, 2009, p. 82). The new way of governing the state represents a new approach to the basic organization, functions and expectations of citizens from the state, also the process of creation of a new type of bureaucracy. For these reasons, the presence of corruption is a sign of a widespread change in the nature and organization of the post-communist administrative system (Lovell, 2005, p. 75).

Slovakia is among the countries that have recently started to use the regulation of beneficial owners to combat illegal activities and increase transparency. It has created its own measure specifically designed to fight corruption in the area of economic interaction between the state and the private sector. China is currently fighting corruption, and the use of an instrument similar to Slovakia could be an appropriate complement to current efforts. The purpose of this paper is to analyze and present the functioning of the Slovak register of beneficial owners, in order to answer a question, whether the registration of beneficial owners is a policy that could help extend and institutionalize the People's Republic of China ("PRC") anti-corruption campaign. For this purpose, we will approach the beneficial owner public policy in general in the next paragraph. The following paragraph will present the specifics in the Slovak concept of the beneficial ownership registration. Subsequently, we will address the beneficial ownership regulations and the anti-corruption campaign in China, especially in terms of the instruments it has used to achieve the set objectives. 


\section{Beneficial Ownership Public Policies}

Beneficial ownership is an area of public policy, which has been evolving in recent years in many countries. The need to adopt rules in this area result from the fact that a legal owner of an entity (either company, trust, foundation or other legal person) registered in an official state database, does not necessarily actually control this entity or benefits from it. Also, the company may be officially owned by another company. This is even more complicated if this parent company has its registered office in the above-mentioned offshore jurisdictions. These structures can be much more complicated in practice and involve many companies. It is also possible to hide the real ownership structure with the use of nominees, who allows their name to appear as a shareholder or owner in the name of someone else (The Secretariat of the Global Forum on Transparency and Exchange of Information, 2019). This anonymity allows companies to be used as a tool for various types of illegal activity. For this reasons, the issue of beneficial owners and their identification has begun to develop, with the term beneficial owner referring to a natural person who has rights that allow him to control the entity or has rights that guarantee his profit from such an entity (Kruger, 2012, p. 10). At the same time, the beneficial owner is not just a theoretical construct, on the contrary, its definition is aimed at practical use. The history of this concept goes back to the past century and is linked to international agreements in the field of taxation, which pursue various objectives, such as the avoidance of double taxation. The term of beneficial owners have been linked in the treaty context to a wide variety of tax policies but it was settled in the 1960s in the specific context of articles 10-12 of the OECD Model (Vann, 2012, p. 33). Its use in the field of financial law continues today, unifying elements are international agreements, for example within the OECD. Recommended practices apply in particular to financial institutions. These recommendations require that financial institutions carry out customer due diligence to identify and verify the identity of clients and their beneficial owners when an event occurs that conditions verification, e.g. carrying out occasional transactions above USD/EUR 15.000 (The Secretariat of the Global Forum on Transparency and Exchange of Information, 2019, p. 9).

At present, regulation of the beneficial ownership is gaining momentum especially in the area of anti-money laundering legislation. On that account, public authorities want to know who benefits from a particular company, to prevent money laundering or financing of terrorist groups. The trend of passing laws that reveal beneficiary owners of companies is global, especially after the Panama papers case. One of the key documents that influenced the way money laundering and terrorism were fought was the Financial Action Task Force ("FATF") Recommendations. The FATF Recommendations issued in 2003 brought beneficial ownership as the key issue to an effective AML regulation. This document has been taken by several countries as a model in the creation of AML legislation, most notable, the European Union. Subsequently, after the issuing the updated edition of the FATF Recommendations in 2012, the EU has revised its AML legislation and prepared its 4th AML directive, where the beneficial owners of companies have been one of the main points of interest (Formisani, 2016, p. 33). The 4th AML Directive obliges all EU Member States to incorporate into their national legal framework provisions requiring legal entities to obtain and hold adequate, accurate, and current information on their beneficial owners. 
This information has to be registered in national beneficial ownership registers which the Member States had to set up. According to the Directive, the need for accurate and up-todate information on the beneficial owner is a key factor in tracing criminals who might otherwise hide their identity behind a corporate structure, especially in the fight against tax crime and terrorism. Access to such data and thus the purpose of their collection is to make it available to the authorities involved in the fight against terrorism and control of the fulfilment of tax obligations of entities (4th AML Directive, Preamble 14). The newest piece of legislation in the EU is the 5th AML Directive. It amended the 4th AML Directive and introduced changes to prevent the financial system from being used for money laundering and funding terrorist activities. With respect to beneficial owners, the 5th AML Directive brought a change towards transparency as the Member States shall make beneficial ownership registers publicly available.

In addition to the EU Member States, several countries have introduced similar legislation in recent years. Very interesting is, for example, the development of the beneficial ownership policy in the United States. Quite recently, on January 1, 2021, H.R. 6395, the William M. Thornberry National Defense Authorization Act for Fiscal Year 2021 became law. Under this act is integrated the Corporate Transparency Act ("CTA"). The CTA requires reporting of persons who own, directly or indirectly, at least $25 \%$ of the ownership interests in a private company, or who control a private company. The CTA covers corporations and limited liability companies. Further regulations will decide whether also partnerships and trusts would have to report. However, there are a number of exceptions to which these rules do not apply. This applies, for example, to publicly traded companies, companies with twenty or more full-time employees, which reported at least $\$ 5$ million of gross receipts on previously filed Federal income tax returns and with an operating presence at a physical office within the US (Sanborn et al., 2021). These rules thus do not reach the general intensity of EU rules and it is certainly possible to anticipate their further development in the future.

Although beneficial ownership policies currently resonate the most in connection with AML rules, their use is also possible in other related sectors. The requirement to reveal beneficial owners of companies is a logical step also in terms of anti-corruption efforts, and it stems from several facts. The most common way in which a public official can hide suspicious property from the public eye is a legal entity that has its own legal personality. If this company is established in a jurisdiction that does not disclose the ownership structures of companies, neither the public nor law enforcement authorities can reveal that a public official has assets that he could not acquire legally. The scale of the problem was eventually confirmed by the Panama papers case, which affected many powerful people around the world. To illustrate the dimensions of this issue, according to the World Bank research of large-scale corruption cases under the Stolen Assets Recovery Initiative, companies with an anonymous ownership structure were used for transactions in 70 percent of corruption cases (Transparency International, 2018).

In this respect, a legal framework that forces a company to disclose its ownership structure has potential to be an effective tool in the fight against corruption in the sense that they reveal existing personal links, increase the costs and technical difficulty of illegal activities 
and multiply the risk of its detection (Transparency International, 2018). Registers of beneficial owners as such will not eliminate corruption. They are not a miracle key to clean up public life, and with more or less difficulty they can be overcome by a determined perpetrator. It is, therefore, necessary to integrate them as one of the measures into a wider range of anti-corruption institutes. Their purpose is to institutionalize anti-corruption mechanisms and to introduce transparency as a standard. In this way, they can make the conditions for corrupt activities more difficult and, together with other measures, have the potential to be an effective tool.

\section{Unique Beneficial Ownership Policy in Slovakia}

The problem of corruption has been present in Slovakia for a long time. For years it was consistently ranked by multiple NGOs and European agencies as one of the most corrupt countries in the European Union (Petit Press a.s., 2016). According to a 2010 survey conducted by the Slovak Business Alliance, corruption was identified by businesspeople and entrepreneurs as the number one barrier to doing business in the country (Furnas and Kicina, 2016). Corruption in the field of public procurement was perceived as the most problematic. Over the past decade, there have been several cases in Slovakia, often in the procurement of large government contracts, where the media or non-profit organizations have pointed out the lack of transparency or possible interconnection of political leaders and successful bidders in the public procurement process. Shell companies registered in tax haven jurisdictions were often used as successful bidders (Patakyova et al., 2018, p. 79). These cases have increased public pressure to demand transparency in state-private trade relations. This demand has led to the gradual adoption of several laws in this area. In November 2015 Slovakia became the first EU Member state to introduce a register of beneficial owners of companies that were doing business with the state. The law established a register where companies registered their beneficial owners and also provided the definition of a beneficial owner, who is an individual (not a company) with at least a quarter share in the company, with the power to appoint or rescind statutory body, or with another mean of controlling the company (Slovak AML Law, para. 6a). This register was published online in an open data format, available for the public. Disclosed were the names and addresses of companies' owners, their nationality, as well as their birthdates. Data indicated whether the beneficial owner was a Slovak government official (Slovak Act on Public procurement, para. 25). Despite the fact that this register has been operational for a relatively short period, it has been perceived quite positively and has contributed to several changes: "Since 2015, the growth of the number of Slovak firms owned in offshore destinations dropped from $10 \%$ annually to $1 \%$. Before 2015 , the year when the register was open, a number of Slovak companies owned through offshore destinations was rising by 10 percent per year." (Sipos, 2017, p. 3).

However critics blamed this register for several shortcomings (Labant and Sipos, 2016), first of all, it was difficult to verify the veracity of the data in the register. Further, the costs of development of the register and yearly operating costs were also rather high. There have also been cases in practice where the data of a person in the register of beneficial owners have been questioned as untrue and other cases where public authorities have entered into 
a contract with a company, even though it has not registered its beneficial owner in the register. Such as contract was against the law and the public body was sanctioned, however, this did not affect the validity of the contract. The above-mentioned criticism, as well as several other reasons, eventually led in 2016 to the replacement of this register for a new Register of public sector partners.

\section{Register of Public Sector Partners}

Act no. 315/2016 Coll. on the Register of Public Sector Partners entered into force on 1 February 2017, this Act, in contrast to previous legislation on the register of beneficial owners of companies, covers the whole spectrum of legal relationships in which a third party accepts any performance from the state, including the sale of state property. As public procurement represents in Slovakia about $20 \%$ of public sector expenditure (Trading Economics, 2021), the previous legislation, which focused solely on the field of public procurement did not, in the opinion of the professional public, sufficiently address the problem of identifying the beneficial owner of the company, which receive funds from the state.

The basis of the new law was the introduction of a new register in which the beneficial owners of specific companies must be registered - the Register of Public Sector Partners (hereinafter as "RPSP"). The administrator and operator of the register is the Ministry of Justice of the Slovak Republic. From the procedural point of view, the register is kept and all proceedings concerning it, take place at one specific court - the District Court of Zilina, which is the competent registering authority for the entire territory of the Slovak Republic.

The change brought by this law followed on from those places where the previous register had failed and tried to bring new solutions beyond the framework of EU directives. The law defines certain subjects as the partners of the public sector. It uses a combination of positive and negative definitions. In the positive definition, it can be either a company or an individual who receives the performance under the contract from the public sector. Typically, we will include in this group mainly companies, but also individuals, participating in public procurement, whether as a supplier or subcontractor, as well as recipients of various types of subsidies and contributions (for example, from state funds, municipal budgets, regions, public organizations or European Structural Funds). In general, it can be stated that their essential feature is the acceptance of a one-time or repeated monetary performance of a higher value. In the negative sense, the legal definition determines that a public sector partner cannot be a person whose performance does not meet the statutory threshold, which is EUR 100.000 in the case of a single performance under the contract and in the case of several partial or recurring performances a contract which total value exceeds EUR 250.000 (Act on the RPSP, para. 2 num. 2 and 3). Partner of the public sector cannot be also a public administration entity, a state enterprise, a bank, an insurance company, another state and an international organization, etc. (Act on the RPSP, para. 2(1)a). The basic rule of the RPSP Act is that if a public sector partner is to receive performance from the public sector it must have registered its beneficial owner through an authorized person. 
As the public sector, the law specifies the state and all state bodies, but also self-governing bodies, state-owned enterprises and various institutions that are connected to the budget of the state (Mamojka, 2017, p. 47).

Registration through an authorized person is also the most fundamental change, which should lead to a higher degree of accuracy of data in the register (Lukacka and Petrek, 2019, p.50). The authorized person may be only a member of precisely specified professions which, due to the nature of their work, have the qualification to be able to perform beneficial owner verification with professional care. The law stipulates that the function of the authorized person may be performed by a lawyer, notary, bank, auditor, tax advisor who have agreed to fulfil the obligations of the authorized person. The authorized person must be independent of the public sector partner and its activity is based on the legal regulation of the contract on control activities, because it implements an independent control activity Ministry of Justice of Slovak Republic, 2016, p. 10). The authorized person may not perform the tasks of verification and identification of the beneficial owner if he is in the given case a public sector partner or a beneficial owner. The same applies if it has any relationship with a public sector partner or members of its bodies that could call into question its impartiality, in particular, if it is personally or financially linked to a public sector partner (Zigo, 2020, p. 33). The RPSP Act introduced a stricter regime of beneficial owner verification. The previous legislation made registration in the register of beneficial owners conditional on an affidavit on beneficial owners of the company, which served as a basis for registration (Slovak Act on Public Procurement, para. 28). This mechanism has been criticized for inadequacy. The RPSP Act set up a complex registration process with verification of the veracity of entries and subsequent sanction mechanisms in case of identified deficiencies. The registration procedure can be initiated only at the proposal of the authorized person. The authorized person is responsible (together with the public sector partner) for the correct and complete identification of the beneficial owner and may use various procedures for this purpose. In principle, it will proceed according to how complex the corporate structure of the public sector partner is. Primarily, it will assess the company's founding documents, articles of association and internal structure. However, the authorized person may proceed as in the case of due diligence, if necessary, and examine the company in detail, i.e. go through the company's accounting, contracts with other entities that would indicate a possible interconnection, etc. (Lacko, 2018, p. 160).

To preserve the veracity of the data entered in the register, the registering authority, i.e. the court, may verify, on its own initiative or the basis of a qualified initiative, the veracity, and completeness of the data on the beneficial owner entered in the register. A qualified complaint may be submitted by anyone, but it must contain a description of the facts justifying a reasonable doubt as to the veracity or completeness of the data (Act on the RPSP, para. 12 num. 2). Failure to provide true and complete information about the beneficial owner or failure to notify a change in the beneficial owner's structure within 60 days can result in a fine of up to EUR 1,000,000 for the public sector partner. A fine may be imposed for breach of the obligations also directly on the statutory body, up to the amount of EUR 100,000. At the same time, an authorized person is a guarantor for the payment of the fine imposed on the statutory body (Act on the RPSP, para. 13). The registering 
authority shall impose a fine of between EUR 10,000 and EUR 100,000 on the authorized person if it violates the requirement of impartiality. Non-payment of the fine may result in the deletion of the public sector partner from the register. A very important sanction is also the possibility of the public sector to withdraw from the contract and demand a refund of the funds provided (Kršjaková, 2019, p. 20).

In legal science and among the professional public in Slovakia, there are still ongoing debates as to whether this model of functioning is set up correctly, what improvements are possible to be made (Petrek, 2018, p. 22). The positive result of this register is certainly that companies receiving benefits from the state have their beneficial owners registered. The share of offshore shell companies involved in public procurement processes also fell quite significantly (Tholtova and Sipos, 2019). As of January 2021, more than 32.000 companies were registered. ${ }^{4}$ Slovakia's position in the Corruption Perception Index has, however, not improved significantly. It has risen by 4 places since 2012, to 59th place, which is average within the region, but there is certainly room for improvement concerning the EU standard. As for the position in the Corruption Perception Index, it is understandable that the growth will not be significant in such a relatively short period. Building trust in state institutions and the fight against corruption is a long-term project that requires, in addition to the RPSP, the interconnection of several institutes that will complement each other and probably also a change of the moral values of the population will be necessary.

\section{Beneficial Owners Policy and Anti-corruption Campaign in China}

This paragraph analyzes the PRC's current regulation in the field of beneficial ownership policy. It also aims the current Chinese government's efforts to fight corruption and what tools have been adopted in this regard. The objective we pursue by dealing with these areas is to analyse the current situation in China in order to answer the question of whether it would be desirable and possible to incorporate into the Chinese legal system a measure such as the register of beneficial owners, to help institutionalize the anti-corruption campaign in the PRC.

\section{The beneficial ownership regulation in China}

Although the legal system of China is based on a different approach than the systems of the EU Member states, globalization also is a consideration in that states are transposing elements from abroad into their national laws. Especially in the area of taxation, where states cooperate on a bilateral and multilateral level, it is impossible to escape approximation. For this reason, the Chinese legal system has been distinguishing beneficial owners for a long time, even though a register similar to the one in Slovakia has not been established in China.

One example where the beneficial ownership policy is used in PRC is the State Taxation Administration of the People's republic of China ("SAT") guidelines for determining beneficial owner status under tax treaties and its Circular on how to interpret and recognize the "beneficial owner" in tax agreements (Guo Shui Han, 2009, No. 601) issued on

\footnotetext{
${ }^{4}$ See Official data from the Register of Public Sector Partners, available at https://rpvs.gov.sk/rpvs.
} 
October 27, 2009. Tax treaties between China and foreign countries operate with the term beneficial owner, for example, in the Agreement between the PRC and the Hong Kong Special Administrative Region for the Avoidance of Double Taxation and the Prevention of Fiscal Evasion concerning Taxes on Income (Lehman et al., 2012). The above-mentioned Circular generally defined the term beneficial owner as a person who has ownership or control over income or the rights or property from which income is derived. The Circular states that beneficial owners, in general, engage in substantive business activities and may be individuals, companies, or other entities (Lehman et al., 2012). Since 2009, the SAT has issued several sets of guidance that address the concept of the beneficial owner and the requirements to qualify for beneficial owner status. On February 3, 2018, the SAT released SAT Public Notice [2018] No. 9 ("Public Notice 9"). Public Notice 9 revokes Circular 601 and older Public Notice 30 and updates the assessment principles for beneficial ownership determination. Public Notice 9 expands the ways in which a non-resident can achieve beneficial owner status (Dwyer, 2018).

Another area where the Chinese administration uses the term beneficial owner is the antimoney laundering legislation. Notice of the People's Bank of China on Further Reinforcing Work Related to Anti-Money Laundering by Financial Institutions, Yin Fa [2008] Circular 391, Section 2.3 states that:

"the natural person that actually controls a customer and the beneficial owner of transactions shall include, but not be limited to the following two categories of people: (i) the actual controller of a company; and (ii) the person who actually controls financial transaction process or is ultimately entitled to a relevant economic benefit (excluding a principal), however, the relevant customer fails to disclose information on such person." (Transparency International, 2016).

In the field of corporate governance, the Company Law of the PRC requires limited liability companies to set up a register of shareholders which states name and address of the shareholders, amount of capital contribution of the shareholders, serial numbers of the capital contribution certificate. Shareholders are required to inform the company regarding changes in company ownership (PRC Company Law, art.32). In the case of listed companies, the law establishes that they should submit annually to the securities authority a list containing the actual controllers of the company. An actual controlling party shall mean a party which exercises actual control over a company as an investor or through other agreements or arrangements even though it is not a shareholder of the company (PRC Company Law, 2018, art. 216). This definition includes investors who control more than $30 \%$ of the voting rights or with powers on the selection of members of the board of directors of the company.

Transparency in the area of ownership structures also affected the area of Foreign Invested Entities. Although the new FDI law relaxed the regime of founding companies, it also brought an information reporting system. "Foreign investors or FIEs shall submit investment information to relevant commerce authorities via the official enterprise registration system and the enterprise credit information public system. The contents and scope of foreign investment information report shall be determined under the 'as needed' principle." (PRC FDI Law, 2019, art.34). This obligation was subsequently 
delineated when the Ministry of Commerce of the PRC ("MOFCOM") and the State Administration for Market Regulation issued new regulation - Measures for Foreign Investment Information Reporting, that took effect on January 1, 2020. One of the key elements of this regulation is an obligation for the foreign investor to "truthfully disclose, among others, the ultimate de facto controller(s) of the subsidiaries they establish in the PRC. The new regulations provide guidance as to the types of the ultimate de facto controller(s) and circumstances under which the ultimate de facto controller(s) should be identified." (Sheng et al., 2020). If a foreign investor fails to fulfil the obligations as required by the foreign investment information report system and fails to make a correction within a prescribed time limit the law also stipulates a sanction - fine in the range of 100,000 Yuan and 500,000 Yuan (PRC FDI Law, 2019, art. 37). MOFCOM directs these measures to push the companies towards the full disclosure of ownership and prevent hiding of the actual owners through private company structures and special purpose vehicles.

From these examples, we can conclude that the concept of the beneficial owner is not unknown in China and is used in various forms either in tax administration, prevention of money laundering or in corporate governance. However, we can see that this legislation is relatively fragmented and does not apply uniformly to all companies. The obligation to report to its beneficial owners in China, in the sense of the above examples, leads to different goals and serves different state authorities. By not establishing a single register where this information is collected, authorities have to rely on the information collected by financial institutions or on basic information contained in the company registry, and timely access to beneficial ownership information by competent authorities is not fully guaranteed (Transparency International, 2016). We can also state that this term is not used uniformly within different branches of law. For example, for tax purposes, the beneficial owner may also be a company, but for AML purposes, it may only be a natural person.

If we take into account the development of beneficial ownership regulation in the world, it is clear that the emphasis is currently on a precise and single definition, collection of data on beneficial owners in one central register accessible to all involved state authorities and uniformity of measures for all companies. A new element gaining emphasis within the EU is the public of data on beneficial owners in the central register, and this is for a simple reason. The state cannot verify the entries of hundreds of thousands of companies in these registers, public involvement will put the veracity of the data under a higher degree of control. As we have shown, the PRC uses the term beneficial owner in industries where it considers it necessary to achieve various partial goals. Moving to a single beneficial ownership policy would allow them to manage the accumulated data more efficiently. At the same time, these data would be usable in all sectors where they have been used so far, but also in new ones. It would therefore be possible to use the established register for the purpose of tax regulation, AML, corporate governance, but it would also open up space for use in the fight against corruption, which we will address in the next paragraph.

The risk of this policy is an increase in the administrative burden for businesses, which may repel potential investors. For this reason, given the large number of companies registered in China, it would be worthwhile to implement a similar model as in the EU, i.e. to make registrations based on affidavits. However, if the register is to be used also 
to fight corruption, then the verification of registrations is a very important element. Therefore, it would be appropriate to take inspiration from the Slovak model to subject the entries to verification, but not a comprehensive one, which would be difficult to perform in China from a practical point of view. Verification should be targeted only to companies whose registration would seem problematic. This would be strengthened by the publication of the register, thus involving the public. A detailed analysis of the disputed entries could then be carried out by a competent public authority empowered to review the company's ownership structure, including bank accounts or contractual relationships. The investigating principle of this proceeding would be multiplied if the burden of proof were reversed and the company would be required to prove that its entry was true.

\section{Anti-corruption campaign in China}

The previous paragraphs have shown that the use of beneficial ownership policy for the purposes of taxes and AML measures is a global trend, also being applied in China. Here we will try to point out why the Slovak model, focused on the fight against corruption, could be (if properly modified) a suitable complement to China's efforts to fight corruption. The anti-corruption campaign is still ongoing in China, beginning with the inauguration of the new President Xi Jinping and it was directly named as one of the goals of the new leadership at the 18th National Congress of the Communist Party of China in 2012. "The Party will establish a sound system for punishing and preventing corruption by fighting it in a comprehensive way, addressing both its symptoms and root cause and combining punishment with prevention, with the emphasis on prevention." (Communist Party of China, 2012).

Corruption is a longer-term problem in China for various reasons, some of which may be related to the transition from a planned to a market economy, but there are also deeper social causes. Of course, corruption gradually had to be noticed by the government for logical and pragmatic reasons. In addition to the economic implications mentioned in the introduction, for China is also very relevant the fact that countries, where corruption is a common phenomenon, may spend less money on public benefit projects, causing the regime to lose support, corruption is also related to the deepening of economic inequality in the country, which again affects the support of people in the state establishment (Uslaner, 2015, p. 207-2011). For these reasons, it is apparent that a state interested in economic development must eliminate corruption to the highest possible extent.

Although there have been few anti-corruption campaigns in China in the past, analysts agree that the ongoing campaign is exceptional in several respects. The first reason is that while previous campaigns have mostly been a response to major corruption scandals, the current campaign is long-term and still ongoing. According to the annual report from the Supreme People's Procuratorate submitted to the national parliament, 18585 people were prosecuted for crimes related to corruption in 2019, a 90 percent year to year increase (The Jakarta Post, 2020). Another aspect is the fact that several senior party officials were convicted, which previously was not possible. Many officials are detained every year, not only at the local level but also at the national level, not excluding the party leadership ("Corruption in China", 2020). Very significant changes are the enhancement 
of the Central Discipline Inspection Commission ("CDIC") anti-corruption power through structural change and reduction of extensive state involvement in the Chinese economy (Manion, 2016, p.3). The competencies and tasks of the CDIC have been clarified to ensure the impartiality of inspectors investigating corruption. Activities of inspectors have to be managed from a higher administrative level than the inspected one, and a rotation system of inspectors (so they operate outside their place of residence), has been introduced to avoid personal relationships and influencing (Manion, 2016, p. 7). The reduction of state involvement in the Chinese economy is characterized by the adoption of measures to reduce administrative control and the number of issued business permits. These measures reduce opportunities for officials to ask for a bribe. It is not a negligible number of measures, "at the national level, China has abolished or reduced approval requirements for thousands of procedures, at local levels for tens of thousands. Doing business in China today requires fewer than half the approvals required 10 years ago" (Manion, 2016, p. 9).

These elements are certainly important, but studies on the anti-corruption campaign in China have also identified shortcomings. First, the campaign lacks significant institutional changes bringing new legal institutes of the fight against corruption, which would operate objectively. On the contrary, the campaign is dominated by subjective elements, which focus more on the detection and public punishment of known persons, which can serve as a public example. ${ }^{5}$ Secondly, existing administrative processes and legal institutes are often circumvented in the prosecution of such persons. Ignoring legal institutions result in even less attention being paid to the rule of law (Zhu et al., 2017, p. 511). Successful anti-corruption campaigns in other jurisdictions set the opposite example. The Hong Kong government conducted an anti-corruption campaign between 1976 and 1990 in which they sought to address corruption as a more complex social problem. The campaign emphasized the connection between corruption and serious social problems. The effectiveness of this anti-corruption campaign was based on increasing public awareness of corruption, change of social attitudes towards corrupt behaviour, enabling penetration of "hard to reach" groups and providing support for the anti-corruption activists (Scott and Gong, 2015, p. 100). The obligation to register beneficial ownership in a publicly available central register could bring the changes needed to fill the missing elements in China's anticorruption efforts. The register as such is a legal institute which, through its objective effect, increases transparency, where authorities will have no reason to circumvent it. The obligation to publish links between public officials or their family members and specific companies gives the public a strong signal that no one is above the law. This fact alone improves the public perception of corruption. Furthermore, if effective verification of the data in the register is involved, it helps to penetrate hidden corporate structures and reveals "hard to reach" groups. For anti-corruption activists, such register is an extraordinary resource for their activities.

As regards areas prone to corruption, public procurement is probably one of the most significant in China. It was reported that some managers of state enterprises used public funds to accept bribery or favour relatives in procurement supplies and construction.

\footnotetext{
${ }^{5}$ Recent case as an example: NY Times. China Sentences Former Bank Chief to Death in Rare Move. Available at https://www.nytimes.com/2021/01/05/business/china-huarong-death-penalty.html?smid=em-share.
} 
Another problem is local protectionism, where local political authorities interfere in contract award procedure, and local businesses are much likely to be chosen, which in turn motivates them to provide undue benefits to local officials and constitutes indirect corruption (Wang and Zhang, 2013, p. 27). The problem in this area is according to several studies (Fang et al., 2018, Zhang et al., 2019) that such practices are not exceptional; on the contrary, as they have become commonplace, it has become a frequent practice that to win a contract, one must have connections or provide a bribe (Gong and Zhou, 2014 , p. 73). One of the leading principles in the procurement legislation of the PRC is transparency (PRC Government Procurement Law, 2014, art. 3), an important factor in the fight against corruption (Smith et al., 2020, p. 94). Use of the beneficial ownership register would aim to promote this fundamental principle to reduce opportunities for corruption, and subsequently to make it difficult to provide a bribe. At present, especially with large amounts of funds, it is not common and practical to hand over a bribe in the form of cash. Linked companies are much more often used to pass a bribe as payment for a fictitious service. For law enforcement authorities, information on beneficial owners is a very important element in detecting such a crime.

The possibility of introducing a register of beneficial owners in the PRC is also interesting from another point of view. China is currently perceived as a technology leader, where many technologies are suitable for use also in the public sector. Through technology, public services are improved and the relationship between government and society is changing, and they can bring greater transparency and efficiency to public organizations. An example of such use of technology is the online budget supervision system in Guangzhou, where improved its information capacity, facilitating much stronger budget oversight (Niu and Lin, 2020, p. 274). With the technological capabilities of the PRC, it would be possible to achieve much higher efficiency of data entry and verification in the registers of beneficial owners than is currently the case in Western states. For example, such a register could be linked to a company register or automatically linked to published public procurement contracts. The big data could then evaluate the risk entries in the registry by comparing it with other available data.

\section{Conclusion}

The article examines public policies of beneficial ownership registration in state registers. These policies have recently gained momentum in many countries, especially in the EU. Although these policies are generally aimed at combating money laundering and terrorist financing, we have focused on their other purpose. We have pointed out the example of Slovakia as a country that has problems with corruption and can use these registers to improve transparency in the field of state management to prevent corruption. What makes the Slovak model unique, is its application outside AML to companies receiving financial benefits from the state, as well as registration using external verifiers of beneficial ownership data and system of sanctions for breach of obligations under this law. The registration of beneficial owners was here a response to the use of shell companies, through which various persons can draw funds from the state. 
The experience in Slovakia and the special use of the register of beneficial owners for the purpose of the fight against corruption were further mentioned in relation to the PRC's efforts to fight corruption. As part of the analysis of the legal status of beneficial owners in China, we found that the use of this institute is fragmented within the different legal branches and the different goals it aims at. A single beneficial ownership policy would allow China to manage the accumulated data more efficiently and would also allow their use in sectors where this has not been possible so far - such as the fight against corruption. This measure is even more relevant when we consider the ongoing anti-corruption campaign in the PRC. Several analyzes criticize the PRC's anti-corruption campaign for "big tigers", large-scale corruption cases that have widespread publicity, but neglect of truly essential institutional elements in the fight against corruption. It is certain that for the campaign itself is essential to prosecute high-ranking criminals, but if it does not bring stable institutes, its influence is not long-lasting. These necessary legal institutes should then focus on increasing transparency and preventing corruption in those sectors that are at risk, whereas one of the riskiest industries in China, we have identified the area of public procurement. Properly designed, the register of beneficial owners can move toward these goals. It can serve as a stable legal institute that operates uniformly and objectively. It can serve several branches of public administration while bringing the necessary transparency in the fight against corruption. In the field of public procurement, it can reveal which person ultimately benefits from state finances.

As for how the beneficial ownership policy in the PRC should be regulated, we believe that China could be inspired partly by the regulation in the EU and partly by the specific regulation - the Slovak regulation, which is aimed specifically at the fight against corruption. The key element in the Slovak model is the verification of registrations. In China from a practical point of view, the verification of data in the register should be targeted only to companies whose registration would seem problematic. As an example, might serve the legislation in the Hong Kong Special Administrative Region, which is inspired by European legislation. ${ }^{6}$ The important part is the online publication of the register, thus involving the public. As an advantage in China in this area, we see technological progress and experience with the use of big data in public administration. With the technological capabilities of the PRC, it would be possible to achieve much higher efficiency of data entry and verification in the registers of beneficial owners than is currently the case in Western states.

However, corruption is not an isolated element, it relates to socio-political realities, culture, norms, and values of a society. Very important are also the institutional arrangements of the government, which play a key role in helping to discourage corrupt behaviour. Procedural factors discouraging corruption include the policies that regulate individual behaviour, performance, and relationships and have been designed to limit the opportunities for corrupt behaviour and activities. The presence of an independent press and working and civil society organizations helps expose corruption and thus serves as an important external control of corruption (Neshkova and Rosenbaum, 2015, p. 111). For this reason, the

\footnotetext{
${ }^{6}$ Hong Kong's Companies Ordinance Act in 2018 introduced new register. Available at https://www.cr.gov.hk/ en/legislation/scr/overview.htm.
} 
adoption of a single instrument to fight corruption cannot eliminate this societal phenomenon. Only the adoption of tools that increase public awareness of corruption, change of social attitudes towards corrupt behaviour, and provide support for the anti-corruption activists can ultimately be effective. Therefore, the register of beneficial owners and its effectiveness depends to some extent on public involvement and its attitude to corruption.

\section{Acknowledgements}

This paper is an output in a project granted by Slovak Research and Development Agency, under Grant APVV-17-0641: Improvement of effectiveness of legal regulation of public procurement within EU law context.

\section{References}

Blazo, O. and Kovacikova, H. (2019). Rule of law assessment - case study of public procurement. European Journal of Transformation Studies, 7(2), 221-236.

Communist Party of China. (2012). Constitution of Communist Party of China (Adopted on Nov. 14, 2012). China.org.cn. Available at https://www.china.org.cn/china/18th_cpc_congress/2012-11/16/content_27138030.htm.

Corruption in China. (2020). South China Morning Post. Available at https://www.scmp. com/topics/corruption-china.

Dwyer, P. (2018). Beneficial Ownership and Safe Harbor Rule in China. China Briefing News. Available at https://www.china-briefing.com/news/china-beneficial-ownershipsafe-harbor-rule-tax-treaty-benefits/.

Fang, L., Lerner, J., Wu, C. and Zhang, Q. (2018). Corruption, government subsidies, and innovation: Evidence from China. Available at https://doi.org/10.3386/w25098.

Findley, M. G. (2012). Global shell games: Testing money launderers' and terrorist financiers' access to shell companies. Griffith University Centre for Governance and Public Policy.

Formisani, R. (2016). Beneficial Ownership and Effective Transparency. In Siclari, D. (Eds.) The new anti-money laundering law: First perspectives on the 4th European Union directive (pp. 25-43). Springer.

Furnas, I. and Kicina, A. (2016). Transparency case study: Public procurement in the Slovak Republic. Sunlight Foundation. Available at https://sunlightfoundation.com/blog/ 2013/08/12/case-study-public-procurement-in-the-slovak-republic/.

Gong, T. and Zhou, N. (2014). Corruption and marketization: Formal and informal rules in Chinese public procurement. Regulation \& Governance, 9(1), 63-76. Available at https:// doi.org/10.1111/rego.12054.

Graycar, A. (2020). Corruption and public administration. In Graycar, A. (Eds.) Handbook on corruption, ethics and integrity in public administration (pp. 1-10). Edward Elgar. Henry, J. S. (2012). The price of offshore revisited. Tax Justice Network. Available at https://www.taxjustice.net/cms/upload/pdf/Price_of_Offshore_Revisited_120722.pdf. 
Kršjaková, Z. (2019). Sanction mechanism of the register of public sector partners in context of public procurement. Bratislava Law Review, 3(2), 18-33. Available at https:// doi.org/10.46282/blr.2019.3.2.143.

Kruger, D. (2012). Who is a beneficial owner? Business Tax and Company Law Quarterly, 3(1), 8-17.

Labant, J. and Sipos, G. (2016). The register of beneficial ownership in Slovakia: Revolutionary transparency, questionable implementation, unsure benefits. Transparency International Slovensko. Available at https://transparency.sk/en/the-register-of-beneficialownership-in-slovakia-revolutionary-transparency-questionable-implementation-unsurebenefits/.

Lacko, P. (2018). Do akej miery zodpovedaju zapisy v registri partnerov verejneho sektora skutočnosti [To what extent do the entries in the register of public sector partners correspond to reality?]. Milniky prava v stredoeuropskom priestore, Comenius University.

Ledeneva, A. (2009). Corruption in Postcommunist societies in Europe: A re-examination. Perspectives on European Politics and Society, 10(1), 69-86. Available at https://doi.org/ 10.1080/15705850802700017.

Lehman, Xu and Lee. (2012). What is the definition of Beneficial Owner? Lehman, Lee \& Xu LLP, Law Firm. Available at https://www.lehmanlaw.com/resource-centre/faqs/taxation/what-is-the-definition-of-beneficial-owner.html.

Lovell, D. W. (2005). Corruption as a transitional phenomenon: Understanding endemic corruption in postcommunist states. In Haller, D. and Shore, C. (Eds.) Corruption: Anthropological perspectives (pp. 65-83). Pluto Press.

Lukacka, P. and Petrek, F. (2019). Register partnerov verejneho sektora a suvisiace povinnosti uchadzacov vo verejnom obstaravani [Register of public sector partners and related obligations of tenderers in public procurement]. Acta Facultatis Iuridicae Universitatis Comenianae, 38(1), 50-66.

Mamojka, M. (2017). The conducting of business by the state - a selective comparison of fundamental theoretical and practical aspects. Notitiae iudiciales Academiae collegii aedilium in Bratislava, 3(2), 45-54.

Mandl, U., Dierx, A. and Ilzkovitz, F. (2008). The effectiveness and efficiency of public spending. Economic papers 31. European Commission.

Manion, M. (2016). Taking China's anticorruption campaign seriously. Economic and Political Studies, 4(1), 3-18. Available at https://doi.org/10.1080/20954816.2016.1152094. Mihalik, S., Vincent, F., Zigo, D. (2019). Otázka korupcie z pohladu trestného práva a kriminológie s dôrazom na proces verejného obstarávania v Slovenskej republike. [The issue of corruption from the point of view of criminal law and criminology with emphasis on the public procurement process in the Slovak Republic]. In PRO LEGAL: deř študentov práva a doktorandov (pp. 106-122). Matej Bel University Press.

Ministry of Justice of Slovak Republic. (2016). Explanatory Memorandum to the RPSP Act.

Neshkova, M. I. and Rosenbaum, A. (2015). Advancing good government through fighting corruption. In Perry, J. L. and Christensen, R. K. (Eds.), Handbook of Public Administration (3rd ed., pp. 97-118). John Wiley \& Sons. 
Niu, M. and Lin, M. (2020). When the power of the purse meets the power of technology: A case study of Guangzhou people's Congress in China. Asia Pacific Journal of Public Administration, 42(4), 274-289. Available at https://doi.org/10.1080/23276665.2020.1821727.

Nye, J. (2017). Corruption and political development: A cost-benefit analysis. Political Corruption, 281-300. Available at https://doi.org/10.4324/9781315126647-26.

Patakyova, M., Gramblickova, B., Mazur, J. and Dutkova, P. (2018). Specificities of Corporate Governance and Financial Regulation of Companies under the Challenges of Sustainability. Comenius University in Bratislava.

Petit Press a.s. (2016). Slovakia is the second most corrupt country in Europe, a report shows. spectator.sme.sk. Available at https://spectator.sme.sk/c/20342765/slovakia-is-thesecond-most-corrupt-country-in-europe-a-report-shows.html.

Petrek, F. (2018). Register partnerov verejneho sektora a pripravovane legislativne zmeny [Register of public sector partners and forthcoming legislative changes]. Ars notaria, 22(2), 15-25.

Sanborn, H. H., Engel, N. A., Magidenko, E., McLaughlin, T. and Millard, B. N. (2021). Corporate transparency act: Federal beneficial ownership disclosure requirements are coming. Schiff Hardin. Available at https://www.schiffhardin.com/insights/publications/ 2021/corporate-transparency-act-federal-beneficial-ownership-disclosure-requirementsare-coming.

Scott, I. and Gong, T. (2015). Evidence-based policy-making for corruption prevention in Hong Kong: A bottom-up approach. Asia Pacific Journal of Public Administration, 37(2), 87-101. Available at https://doi.org/10.1080/23276665.2015.1041222.

Sheng, J., Xu, C. and Cai, W. (2020). Implementing China's new foreign investment law, part one: Reporting requirements. Pillsbury Law. Available at https://www.pillsburylaw.com/en/news-and-insights/china-new-foreign-investment-law-part-one-reporting-requirements.html.

Sipos, G. (2017). How to make beneficial ownership register work: Lessons from the Slovak beneficial ownership register. Transparency International Slovakia.

Smith, R. G., Oberman, T. and Fuller, G. (2020). Corruption of public officials by organised crime: Understanding the risks, and exploring the solutions. In Graycar, A. (Eds.) Handbook on Corruption, Ethics and Integrity in Public Administration, 80-96.

The Jakarta Post. (2020, May 26). Corruption convictions nearly double in China over last year. Available at https://www.thejakartapost.com/news/2020/05/26/corruption-convictions-nearly-double-in-china-over-last-year-.html.

The Secretariat of the Global Forum on Transparency and Exchange of Information. (2019). A Beneficial Ownership Implementation Toolkit. Available at https://www.oecd. org/tax/transparency/beneficial-ownership-toolkit.pdf.

Tholtova, B. and Sipos, G. (2019). Schránkové firmy sa zlakli a stahujú sa - na Slovensko [Shell companies in fear, moving their seat - To Slovakia]. Transparency International Slovakia. Available at https://transparency.sk/sk/schrankove-firmy-sa-zlakli-a-stahuju-sana-slovensko/. 
Trading Economics. (2021). Slovakia government spending. Available at https://tradingeconomics.com/slovakia/government-spending.

Transparency International. (2016). China Beneficial Ownership Transparency. Transparency.org. Available at https://www.transparency.org/files/content/publication/2015_BOCountryReport_China.pdf.

Uslaner, E. M. (2015). The Consequences of Corruption. In Heywood, P. M., (Eds.) Routledge handbook of political corruption (pp. 199-212). Routledge.

Vann, R. J. (2012). Beneficial Ownership: What Does History (and Maybe Policy) Tell Us. Sydney Law School Research Paper No. 12/66. Available at https://ssrn.com/abstract $=2144038$.

Wang, P. and Zhang, X. (2013). Regulating the procurement of state enterprises in China: Current status and future policy considerations. Frontiers of Law in China, 8(1), 1-35.

Zhang, J., Quan, S. and Jiang, J. (2019). Corruption and private firms' survival in transition economies: Evidence from China. China Economic Review, 57, 101339.

Zhu, J., Huang, H. and Zhang, D. (2017). "Big tigers, big data": Learning social reactions to China's Anticorruption campaign through online feedback. Public Administration Review, 79(4), 500-513. Available at https://doi.org/10.1111/puar.12866.

Zigo, D. (2020). Postavenie advokata ako opravnenej osoby podla zakona o registri partnerov verejneho sektora [Status of advocates as authorized persons according to the Act on the Register of Public Sector Partners]. In Bratislava legal forum. Comenius University in Bratislava.

\section{Legislation}

Act no. 315/2016 Coll. on the Register of Public Sector Partners and Amendments to Certain Acts (promulgated by the National Council of the Slovak republic, Oct. 25, 2016, effective Feb. 1, 2017).

Act No. 343/2015 Coll. Act on Public Procurement and on the Alteration and Amendment of Some Acts (promulgated by the National Council of the Slovak republic, November. 15, 2015, effective Jan. 1, 2016).

Act No. 297/2008 Coll. Act on protection against money laundering and terrorist financing and on the amendment to certain acts (promulgated by the National Council of the Slovak republic, July. 2, 2008, effective Sept. 1, 2008).

Directive (EU) 2015/849 of the European Parliament and of the Council of 20 May 2015 on the prevention of the use of the financial system for the purposes of money laundering or terrorist financing, amending Regulation (EU) No 648/2012 of the European Parliament and of the Council, and repealing Directive 2005/60/EC of the European Parliament and of the Council and Commission Directive 2006/70/EC. (4th AML Directive).

Directive (EU) 2018/843 of the European Parliament and of the Council of 30 May 2018 amending Directive (EU) 2015/849 on the prevention of the use of the financial system for the purposes of money laundering or terrorist financing, and amending Directives 2009/138/EC and 2013/36/EU. (5th AML Directive).

Guo Shui Han, 2009, No. 601. 
Zhonghua renmin gongheguo zhengfu caigou fa (中华人民共和国政府采购法) [Government Procurement Law of the People's Republic of China] (promulgated by the Standing Comm. National People's Cong., Aug. 31, 2014, effective Aug. 31, 2014), (CHINALAWINFO).

Zhonghua renmin gongheguo waishang touzi fa (中华人民共和国外商投资法) [Foreign Investment Law of the People's Republic of China] (promulgated by the 13th National People's Cong., March 15, 2019, effective Jan. 1, 2020), (PKULAW.COM).

Gongsi Fa (公司法) [Company Law] (promulgated by the Standing Committee of the National People's Congress, 26 October 2018, effective 26 October 2018). Article 32. 